\title{
Analisis pengaruh variasi elektroda las e6013 dan e7018 terhadap kekuatan tarik dan kekerasan pada bahan baja ss 400
}

\section{Abdus Shomad*, M. Shahar Mushfi}

Teknik Mesin Program Vokasi Universitas Muhammadiyah Yogyakarta, Jln Kampus Terpadu UMY Jl.Lingkar Selatan Tamantirto, Bantul Yogyakarta Telpon (0274) 38765; ext 265, (0274) 387646 psw.186.

^Email : abdusshomad@umy.ac.id/somach80@gmail.com

\section{ARTICLE INFO}

Article History:

Received February 2017

Accepted October 2017

Available online 30 December 2017

Keywords:

Electrode

SMAW

Tensile strength

Hardnes

SS 400

In cooperation with SNMI XI 2017

Special Edition

\section{ABSTRACT}

Development of technology in the field of construction is increasingly advanced today, will not be separated from technology or welding techniques because it has a very important role in engineering and metal repairs. This study aims to determine the effect of electrode to tensile strength and hardness of SMAW welding on SS 400 steel. The material is given welding treatment with electrode variation E6013 and E7018 diameter of $3.2 \mathrm{~mm}$ by using SMAW DC reverse polarity ie the electrode holder is connected to positive pole and the parent metal is connected With a negative pole. The type of camp used is $V$. The highest tensile strength occurred in the specimens of raw materials that amounted to $432.49 \mathrm{MPa}$ which increased by $10.41 \mathrm{MPa}$ from group E7018. The highest yield strength occurred in the raw materials specimens of 308.53 MPa which had an increase of 9.31 MPa from the E7018 electrode variation group. The highest hardness level occurs in the weld metal part of E7018 electrode variation group that is equal to $189.6 \mathrm{~kg} / \mathrm{mm}^{2}$.

\section{PENDAHULUAN}

Negara Indonesia termasuk salah satu negara yang mempunyai potensi pengembangan dibidang konstruksi dan manufaktur. Sektor konstruksi dan manufaktur memiliki peranan penting dalam perekonomian negara karena mempengaruhi sebagian besar sektor perekonomian negara dan merupakan kontributor penting bagi proses pembangunan infrastruktur yang menyediakan fondasi fisik di mana upaya pembangunan dan peningkatan standar kehidupan dapat terwujud. Oleh karena itu, seiring dengan persiapan sektor konstruksi dan manufaktur menuju perkembangan lebih lanjut, kebutuhan akan material logam dan baja merupakan potensi bisnis yang dapat berpotensi pendongkrak pertumbuhan ekonomi nasional.

Kemajuan teknologi pengelasan logam memberikan dampak yang positif terhadap kemudahan manusia dalam menjalankan aktifitas kehidupannya. Dewasa ini perkembangan ilmu pengetahuan di bidang konstruksi dan logam, tidak 
akan terlepas dari teknologi atau teknik pengelasan karena mempunyai peranan yang sangat penting dalam rekayasa serta reparasi logam. Pembangunan konstruksi dengan logam pada zaman modern seperti saat ini banyak melibatkan unsur pengelasan khususnya dalam bidang rancang bangun yang sangat memerlukan ketrampilan yang tinggi bagi pengelasnya agar diperoleh sambungan las dengan kualitas yang baik dan sesuai dengan standar yang berlaku. Lingkup penggunaan teknik pengelasan dalam konstruksi sangat luas meliputi pembuatan jembatan, pengelasan kapal, rangka baja, sarana transportasi, rel kereta api, sarana transportasi, pipa saluran, dan sebagainya.

Mengelas menurut Wiryosumarto (2000) adalah suatu aktifitas menyambung dua bagian benda atau lebih dengan cara memanaskan atau menekan atau gabungan dari keduanya sedemikian rupa sehingga menyatu seperti benda utuh. Penyambungan bisa dengan atau tanpa bahan tambah (filler metal) yang sama atau berbeda titik cair maupun strukturnya.

Hasil penelitian Santoso (2011) pengaruh arus listrik terhadap kuat pengelasan terhadap kekuatan tarik dan struktur mikro las SMAW dengan elektroda E7016 dengan metode penelitian eksperimental. Untuk memperoleh hasil tentang analisis besarnya kekuatan tarik dan struktur mikro baja karbon rendah yang telah mengalami pengelasan SMAW dengan variasi kuat arus, material yang dipakai adalah baja karbon rendah. Hasil kekuatan tarik sambungan las raw material $36,711 \mathrm{kgf} / \mathrm{mm} 2$. nilai kekuatan tarik dengan kuat arus pengelasan 100 Amper yaitu $31,863 \mathrm{kgf} / \mathrm{mm} 2$. Sedangkan dengan kuat arus pengelasan 125 Amper 40,827 kgf/mm2. Pada kuat arus pengelasan 150 Amper 48,503 kgf/mm2. Struktur mikro logam induk terdiri dari perlit dan ferrit, struktur mikro daerah HAZ. Struktur mikro daerah $\mathrm{HAZ}$ dan logam las dengan kuat arus pengelasan 150 Ampere terdiri dari bainit dan widmanstatten ferrite. Struktur mikro daerah HAZ dan logam las dengan kuat arus pengelasan 100 dan 125 Ampere terdiri dari asutenit sisa dan widmanstatten ferrite.

Hasil penelitaan Prasetyo (2006) terhadap kekuatan tarik dari sambungan las baja tahan karat AISI 304 dengan baja karbon rendah SS 400. Tegangan maksimum dari sambungan las ini adalah 455,52 Mpa, sedangkan tegangan luluhnya adalah 411,83 Mpa. Reduksi penampang yang terjadi sebesar $46,07 \%$.

Hasil penelitian Santoso (2005) terhadap pengaruh arus pengelasan terhadap kekuatan tarik dan ketangguhan las SMAW terhadap elektroda E7018. Penelitian ini bertujuan untuk mengetahui ada tidaknya pengaruh arus pengelasan terhadap kekuatan tarik, kekerasan, struktur mikro dan ketangguhan baja paduan rendah hasil pengelasan SMAW dengan elektroda E7018, penelitian ini memakai 3 jenis variasi arus yaitu 100 amper, 130 amper dan 160 amper. Data yang telah diperoleh dari penelitian ini dari 3 jenis variasi ditunjukan kelompok variasi 130 amper yang terlihat memiliki nilai paling tinggi dari semua pengujian karena struktur mikro ferit acicular lembut yang berupa bilah-bilah menyilang lebih optimal, sehingga menahan rambatan retak yang terjadi.

\section{METODE PENELITIAN}

Alat dan Bahan penelitian

Peralatan utama yang digunakan dalam penelitian ini, antara lain: las SMAW dengan variasi elektroda E7018 dan E6013.

Spesifikasi benda uji yang digunakan dalam eksperimen ini adalah sebagai berikut:

1. Bahan yang digunakan adalah plat baja karbon rendah SS 400.

2. Ketebalan plat $10 \mathrm{~mm}$.

3. Elektroda yang digunakan adalah jenis E7018 dan E6013.

4. Posisi pengelasan dengan menggunaklan posisi bawah tangan.

5. Arus pengelasan yang digunakan adalah 70-130 Ampere.

6. Kampuh yang digunakan jenis kampuh $\mathrm{V}$ terbuka, jarak celah plat $2 \mathrm{~mm}$, tinggi akar $2 \mathrm{~mm}$ dan sudut kampuh $70^{\circ}$.

7. Bentuk spesimen mengacu pada standar JIS Z untuk pengujian kekerasan.

8. Bentuk spesimen mengacu pada standar JIS Z 2201 untuk pengujian tarik.

\section{Pelaksanaan Penelitian}

1. Persiapan Penelitian

a. Persiapan Bahan

Bahan yang diperlukan dalam penelitian ini adalah baja karbon rendah SS 400 dengan ukuran panjang $200 \mathrm{~mm}$, lebar $100 \mathrm{~mm}$, tebal $10 \mathrm{~mm}$. Elektroda jenis E7018 dan E6013 dengan diameter $3,2 \mathrm{~mm}$.

b. Persiapan Alat-alat

1. Mesin gergaji beserta kelengkapannya

2. Mesin sekrap

3. Mesin frais

4. Peralatan pengelasan

5. Mesin las SMAW DC

6. Mesin gerinda tangan

7. Penggaris

8. Kikir

9. Mesin uji struktur mikro

10. Mesin uji kekerasan

11. Stopwatch

12.Pengukur sudu 


\section{Pembuatan Kampuh $\mathrm{V}$ terbuka}

Pembuatan kampuh $\mathrm{V}$ terbuka dengan menggunakan mesin frais. Bahan yang telah dipersiapkan dipotong dengan mesin gergaji, dengan ukuran panjang $200 \mathrm{~mm}$ dan lebar $100 \mathrm{~mm}$ sebanyak dua buah, setelah bahan dipotong kemudian permukaan digambar dengan spidol, tepi permukaan diukur sedalam dua $\mathrm{mm}$ dan di ukur sudut $35^{\circ}$. Setelah bahan digambar bahan dicekam dan dilakukan pengefraisan dengan sudut $35^{\circ}$.

\section{Proses Pengelasan Benda.}

Langkah-langkah yang dilakukan dalam proses pengelasan adalah:

a. Mempersiapkan mesin las SMAW DC sesuai dengan pemasangan polaritas terbalik.

b. Mempersiapkan benda kerja yang akan dilas pada meja las.

c. Posisi pengelasan dengan menggunakan posisi pengelasan mendatar atau bawah tangan.

d. Posisi pengelasan dengan menggunakan posisi pengelasan mendatar atau bawah tangan.

e. Mempersiapkan elektroda sesuai dengan arus dan ketebalan plat, dalam penelitian ini dipilih elektroda jenis E7018 dan E6013 dengan diameter elektroda 3,2 $\mathrm{mm}$.

f. Menyetel ampere meter yang digunakan untuk mengukur arus pada posisi jarum nol, kemudian salah satu penjepitnya dijepitkan pada kabel yang digunakan untuk menjepit elektroda. Mesin las dihidupkan dan elektroda digoreskan sampai menyala. Ampere meter diatur pada angka 130 A. Selanjutnya mulai dilakukan pengelasan untuk spesimen dengan arus $130 \mathrm{~A}$, bersamaan dengan hal itu dilakukan pencatatan waktu pengelasan.

\section{Pembuatan spesimen}

Mengacu standar JIS Z 22011981 untuk pengujian kualitas kekuatan tarik bahan, penulis memilih spesimen dengan standart ini karena sesuai dengtan dimensi benda yang di pakai dalam penelitian ini.

Setelah proses pengelasan selesai maka dilanjutkan pembuatan spesimen sesuai JIS Z 2201 1981, yang nantinya akan diuji tarik, langkahlangkahnya sebagai berikut:

1) Meratakan alur hasil pengelasan dengan mesin frais.

2) Bahan dipotong-potong dengan ukuran panjang $200 \mathrm{~mm}$ dan lebar $22 \mathrm{~mm}$.
3) Membuat gambar pada kertas yang agak tebal atau mal mengacu ukuran standar JIS Z 2201 1981.

4) Gambar atau mal ditempel pada bahan selanjutnya dilakukan pengefraisan sesuai dengan bentuk gambar dengan menggunakan pisau frais diameter $60 \mathrm{~mm}$.

5) Bahan yang sudah terbentuk tersebut dirapikan permukaannya dengan kikir yang halus, selanjutnya benda diampelas sampai halus.

Mengacu standar JIS Z 2202 1980. Setelah proses pengelasan selesai maka dilanjutan pembuatan spesimen sesuai JIS Z 2202 1980, yang nantinya akan diuji kekerasan, penulis memilih spesimen dengan standart ini karena sesuai dengtan dimensi benda yang di pakai dalam penelitian ini, langkah-langkahnya sebagai berikut:

1) Meratakan alur pengelasan menggunakan mesin frais.

2) Bahan dipotong dengan lebar $58 \times 12 \times 12$ $\mathrm{mm}$. Setelah itu difrais untuk mendapatkan ukuran sesuai standar JIS Z 22021980.

3) Setelah proses selesai kemudian benda kerja dirapikan dengan kikir dan dihaluskan menggunakan ampelas.

4) Setelah diampelas untuk mendapatkan permukaan yang lebih halus maka diberi autosol.

5) Benda yang telah diberi autosol dimasukkan kedalam cairan etza dan kemudian dibilas dengan alkohol dan air sehingga kita dapat melihat daerah logam lasnya.

6) Setelah didapat daerah logam lasnya maka pada daerah itu diberi takikan sesuai dengan sesuai dengan standar JIS Z 22021980.

5. Pengujian tarik

Prosedur dan pembacaan hasil pada pengujian tarik adalah sebagai berikut. Benda uji dijepit pada ragum uji tarik, setelah sebelumnya diketahui penampangnya, panjang awalnya dan ketebalannya.
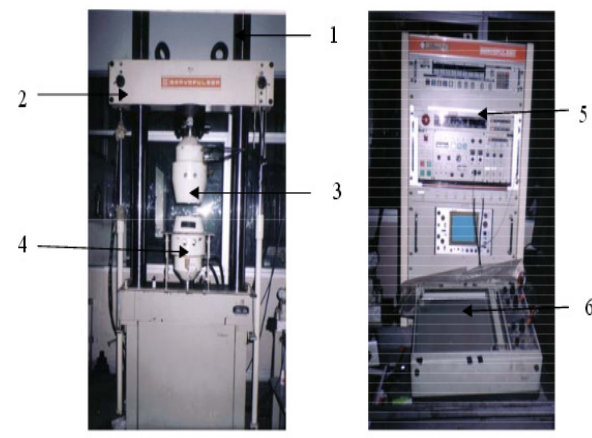

Gambar 1. Mesin uji tarik hydrolic servo pulser 
Keterangan gambar :

1. Batang hidrolik

2. Dudukan ragu

3. Ragum atas

4. Ragum bawah

5. Pembacaan skala

6. Meja plotter

1. Pengujian Kekerasan

Spesimen yang telah jadi, selanjutnya digunakan untuk pengujian kekerasan. Spesimen sebelumnya dipoles terlebih dahulu dengan menggunakan autosol, kemudian dietsa jenis $\mathrm{HNO}_{3}$

Langkah pengujian:

a. Memasang indentor piramida intan.

b. Penekanan piramida intan $136^{\circ}$ dipasang pada tempat indentor mesin uji, kencangkan secukupnya agar penekan intan tidak jatuh.

c. Memberi garis warna pada daerah logam las, HAZ dan logam induk yang akan diuji.

d. Meletakkan benda uji di atas landasan.

e. Menentukan beban utama sebesar $1 \mathrm{kgf}$.

f. Menentukan titik yang akan diuji.

g. Menekan tombol indentor.

h. Pengukur diagonal bekas injakan indentor

i. Tuas penggerak kiri-kanan spesimen

j. Tombol identor

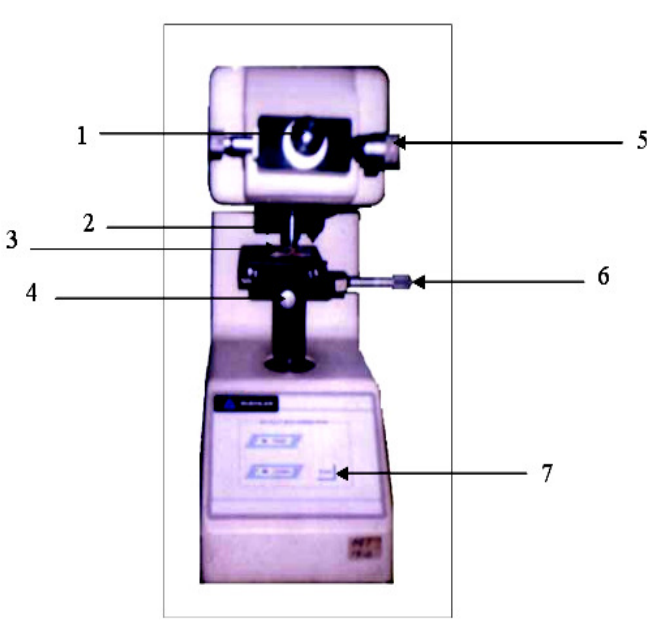

Gambar 2. Mesin uij kekerasan mikro Vickers

Keterangan gambar:

1) Lensa

2) Indentor Vickers

3) Landasan specimen
4) Tuas penggerak maju-mundur specimen

5) Pengukur diagonal bekas injakan indentor

6) Tuas penggerak kiri-kanan spesimen

7) Tombol indentor

\section{HASIL DAN PEMBAHASAN}

Pengujian kekerasan menghasilkan data dari nilai kekerasan dari spesimen kelompok raw materials dan kelompok variasi elektroda. Nilai kekerasan dari setiap spesimen dimasukkan kedalam Tabel dibawah:

Tabel 1. Hasil uji kekerasan vickers variasi elektroda E6013 dan E70.

\begin{tabular}{|c|c|c|c|c|}
\hline \multirow[t]{2}{*}{ NO } & \multirow[t]{2}{*}{ Daerah } & \multicolumn{2}{|c|}{ Specimen } & \multirow[b]{2}{*}{$\begin{array}{c}\text { RAW } \\
\text { Materials }\end{array}$} \\
\hline & & E6013 & E7018 & \\
\hline & Logam & 172,2 & 189,6 & - \\
\hline 1 & Las & & & \\
\hline 2 & $\mathrm{HAZ}$ & 154,5 & 153,6 & - \\
\hline 3 & $\begin{array}{l}\text { Logam } \\
\text { Induk }\end{array}$ & - & - & 141.6 \\
\hline
\end{tabular}

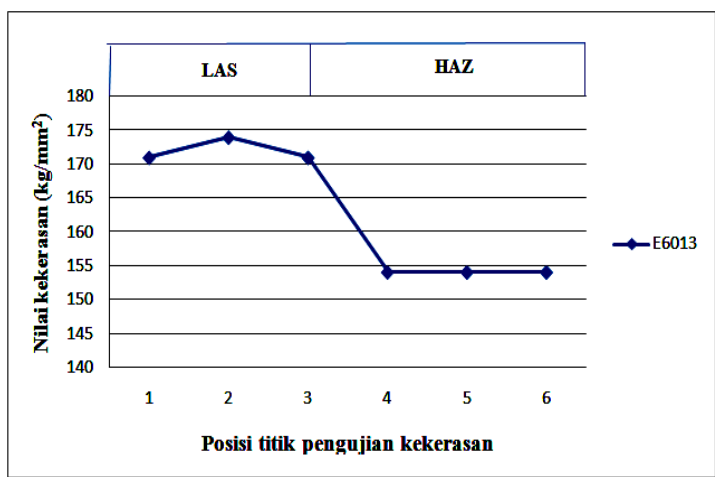

Gambar 3. Menunjukan nilai kekerasan elektroda E6013.

Gambar diatas menunjukan bahwa titik 1 sampai 3 adalah nilai untuk kekerasan daerah logam las nilai rata-ratanya dalah $172,2 \mathrm{~kg} / \mathrm{mm}^{2}$. Titik 4 sampai 6 adalah daerah HAZ yang mempunyai kekerasan rata-rata $154,5 \mathrm{~kg} / \mathrm{mm}^{2}$. Sedangkan pada titik 6 sampai 9 adalah daerah logam induk karena dalam pengujian ini daerah logam induk hanya di uji pada spesimen raw 
materials jadi tidak ada pada spesimen E6013. Nilai kekerasan tertinggi pada spesimen dengan variasi elektroda E6013 terletak di daerah logam las yaitu sebesar $174,3 \mathrm{~kg} / \mathrm{mm}^{2}$.

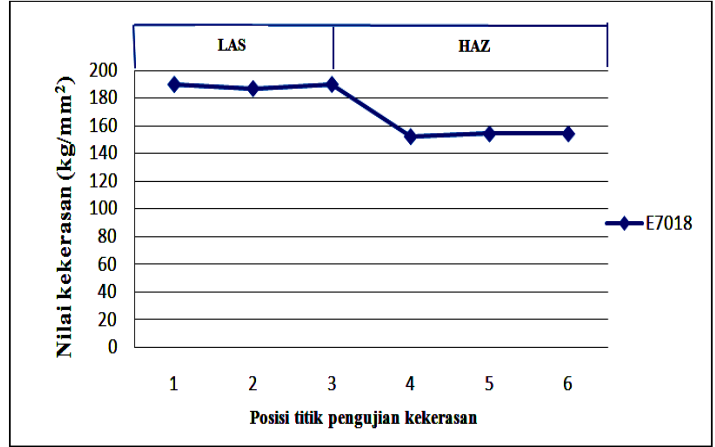

Gambar 4. Menunjukan nilai kekerasan elektroda E7018.

Gambar diatas menunjukan bahwa titik 1 sampai 3 adalah nilai untuk kekerasan daerah logam las nilai rata-ratanya dalah $189,6 \mathrm{~kg} / \mathrm{mm}^{2}$. Titik 4 sampai 6 adalah daerah HAZ yang mempunyai kekerasan rata-rata $153,6 \mathrm{~kg} / \mathrm{mm}^{2}$. Sedangkan pada titik 6 sampai 9 adalah daerah logam induk karena dalam pengujian ini daerah logam induk hanya di uji pada spesimen raw materials jadi tidak ada pada spesimen E7018. Nilai kekerasan tertinggi pada spesimen dengan variasi elektroda E7018 terletak di daerah logam las yaitu sebesar $190,8 \mathrm{~kg} / \mathrm{mm}^{2}$.

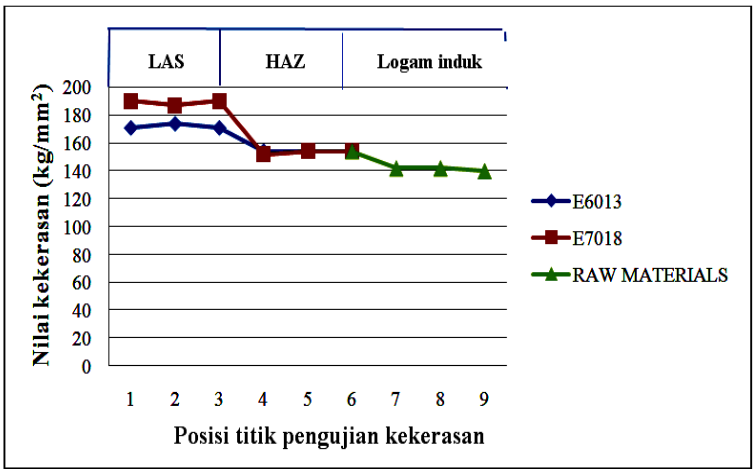

Gambar 5. Nilai kekerasan

Gambar diatas merupakan gabungan nilai kekerasan hasil pengelasan dengan variasi elektroda E6013, E7018 dan raw materials. Nilai kekerasan dari elektroda E7018 merupakan nilai kekerasan spesimen paling tinggi diantara variasi elektroda E6013 dan raw materials.

1. Hasil Uji Kekuatan Tarik

Pengujian tarik dilakukan untuk mengetahui sifat-sifat mekanis dari material baja paduan rendah SS 400 sebagai material uji dalam penelitian ini. Hasil pengujian tarik pada umumnya adalah parameter kekuatan (kekuatan tarik dan kekuatan luluh), parameter keliatan atau keuletan yang ditunjukkan dengan adanya persentase perpanjangan dan persentase kontraksi atau reduksi penampang.

Pengujian dengan menggunakan mesin servopulser pada skala beban 10 ton dan suhu kamar. Spesimen pengujian terdiri dari pengujian tarik untuk kualitas kekuatan tarik baja paduan rendah SS 400 hasil pengelasan SMAW dengan variasi elektroda E7018 dan E6013.

Tabel 2. Hasil uji tarik variasi elektroda E6013 dan E7018

\begin{tabular}{|c|c|c|c||}
\hline \hline Parameter & \multicolumn{2}{|c|}{ Specimen } \\
\hline & Raw Materials & $\mathrm{E} 6013$ & $\mathrm{E} 7018$ \\
\hline$\sigma u(\mathrm{MPa})$ & 432,49 & 283,80 & 422,08 \\
\hline$\sigma_{\mathrm{Y}}(\mathrm{Mpa})$ & 308,53 & 284,33 & 299,22 \\
\hline$\varepsilon(\%)$ & 35,6 & 4,8 & 20,6 \\
\hline
\end{tabular}

Data dari tabel 2, pengujian tarik selanjutnya akan dimasukkan kedalam diagram batang seperti dibawah ini:

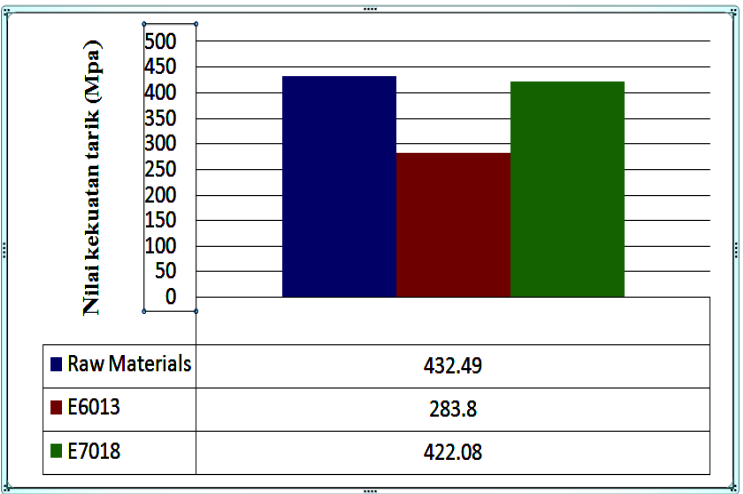

Gambar 6. Diagram hasil kekuatan tarik

Nilai kekuatan tarik untuk raw materials adalah 432,49 MPa. Nilai kekuatan tarik untuk kelompok elektroda E6013 adalah 283,80 MPa, ini berarti mengalami penurunan sebesar 148,69 MPa dari raw materials. Nilai kekuatan tarik untuk kelompok elektroda E7018 adalah 422,08 MPa, hal ini juga mengalami penurunan sebesar 10,41 MPa dari kelompok raw materials dan mengalami kenaikan sebesar 138,28 MPa dari kelomopok elektroda E6013. 


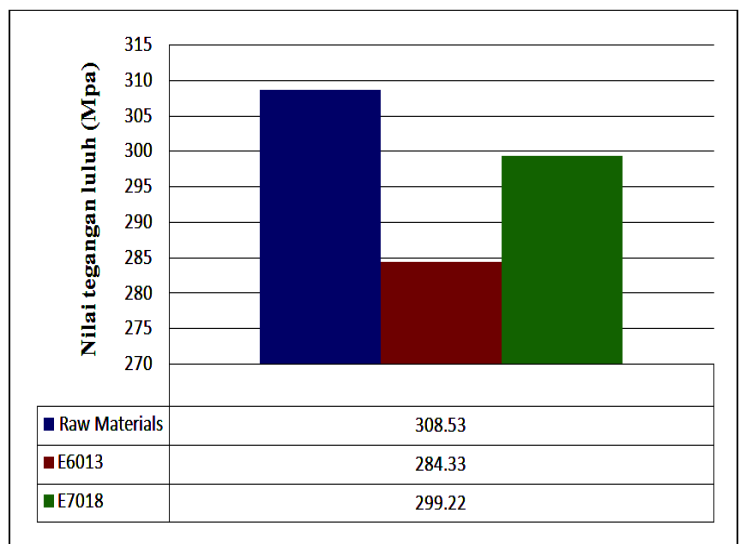

Gambar 7. Diagram untuk tegangan luluh.

Data dari gambar 6 menunjukan bahwa nilai tegangan luluh untuk raw materials adalah 308,53 $\mathrm{MPa}$. Nilai tegangan luluh untuk kelompok elektroda E6013 adalah 284,33 $\mathrm{MPa}$, ini berarti mengalami penurunan sebesar $24,20 \mathrm{MPa}$ dari raw materials. Nilai tegangan luluh untuk kelompok elektroda E7018 adalah 299,22 MPa, hal ini juga mengalami penurunan sebesar $9,31 \mathrm{MPa}$ dari kelompok raw materials dan mengalami kenaikan sebesar 14,89 MPa dari kelomopok elektroda E6013.

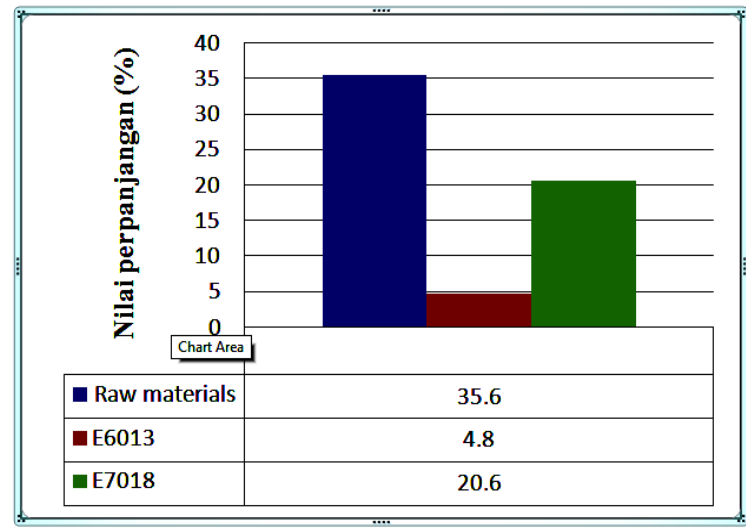

Gambar 7. Diagram perpanjangan

Data dari gambar 7 menunjukan bahwa nilai perpanjangan untuk raw materials adalah $35,6 \%$. Nilai perpanjangan untuk kelompok elektroda E6013 adalah 4,8 \%, ini berarti mengalami penurunan sebesar $30,8 \%$ dari raw materials. Nilai perpanjangan untuk kelompok elektroda E7018 adalah 20,6\%, hal ini juga mengalami penurunan sebesar $15 \%$ dari kelompok raw materials dan mengalami kenaikan sebesar $15,8 \%$ dari kelomopok elektroda E6013.

\section{Pembahasan}

Data dari hasil penelitian diketahui ada perbedaan kekerasan dan kekuatan tarik dari kelompok raw materials dan kelompok yang dikenai proses pengelasan dengan variasi elektroda, yaitu E6013 dan E7018.

Data dari hasil pengujian kelompok variasi elektroda E6013 mempunyai ketangguhan paling kecil dibandingkan dengan kelompok variasi elektroda E7018 dan raw materials. Ini terbukti data yang di peroleh dari uji tarik dan kekerasan bahwa kelompok variasi elektroda E6013 mempunyai nilai ketangguhan paling kecil.

Pengujian yang pertama adalah pengujian tarik untuk kelompok elektroda E6013 nilai kekuatan tarik, tegangan luluh dan reduksi penampang untuk kualitas baja paduan rendah SS 400 mempunyai nilai yang paling kecil diantara kelompok elektroda E7018 dan raw material. Hal ini disebabkan beberapa faktor salah satu penyebabnya adalah karena jenis elektroda E6013 mempunyai kekuatan tarik yang lebih rendah dibandingkan dengan elektroda E7018, hal tersebut bisa dilihat dari dua digit kode angka pertama yaitu 60 yang berarti kekuatan tariknya sebesar 60000 psi dibandingkan dengan elektroda E7018 yang dimana kode angka dua digit pertamanya adalah 70 yang berarti kekuatan tariknya adalah 70000 psi.

Selain karena kekuatan tariknya yang berbeda antara elektroda E6013 dan E7018 hal yang mempengaruhi kenapa nilai kekuatan tarik elektroda E6013 lebih rendah dibandingkan dengan E7018 adalah terletak pada selaput elektroda tersebut untuk elektroda E7018, selaput elektroda jenis ini adalah serbuk besi mengandung hydrogen yang rendah kurang dari $5 \%$, sehingga deposit las dapat bebas dari porositas. Sehingga ketika saat proses pengelasan cairan logam akan lebih mudah terlihat maka dari itu tingkat porositas akan lebih berkurang.

Jika dibandingakan dengan jenis elektroda E6013 berselaput rutil sehingga proses menembusannya sedang, antara fluks dengan cairan logam akan susah untuk dilihat maka dari itu tingkat porositas akan lebih tinggi, jadi kemungkinan untuk terak terperangkam dalam logam las akan lebih tinggi.

Pengujian yang kedua adalah uji kekerasan, pada daerah logam las spesimen variasi elektroda E7018 terjadi nilai kekerasan yang tinggi dibandingkan dengan yang lainnya, hal ini disebabkan kandungan dalam elektroda E7018 adalah low hydrogen sehingga mempengaruhi proses pendinginan logam las, karena elektroda E7018 mempunyai hydrogen yang rendah maka 
proses pendinginan akan lebih cepat sehingga logam las akan menjadi lebih keras.

Beda dengan elektroda E6013 yang kadar hydrogennya tidak lebih rendah dari pada elektroda E7018 maka proses pendinginan yang terjadi tidak secepat pada spesimen variasi elektroda E7018, sehingga tingkat kekerasannya lebih rendah jika dibandingkan dengan spesimen elektroda E7018.

\section{KESIMPULAN}

1. Nilai rata-rata kekuatan tarik, tegangan luluh dan regangan untuk spesimen variasi elektroda E6013 mepunyai nilai yang paling rendah jika dibandingkan dengan kelompok lainnya yaitu sebesar 283,80 Mpa untuk kekuatan tarik, mengalami penurunan sebesar 148,69 Mpa dari kelompok raw materials dan mengalami penurunan sebesar 138,28 Mpa dari kelompok variasi elektroda E7018. Nilai untuk tegangan luluh sebesar 284,33 Mpa, mengalami penurunan sebesar 24,20 Mpa dari kelompok raw materials dan mengalami penurunan sebesar 14,89 Mpa dari kelompok variasi elektroda E7018. Nilai untuk regangan sebesar $4,8 \%$, mengalami penurunan sebesar 30,8 \% dari kelompok raw materials dan mengalami penurunan sebesar 15,8 \% dari kelompok variasi elektroda E7018.

2. Nilai rata-rata kekuatan tarik, tegangan luluh dan regangan untuk spesimen raw materials mempunyai nilai yang paling tinggi jika dibandingkan dengan kelompok lainnya yaitu sebesar 432,49 Mpa untuk kekuatan tarik, mengalami kenaikan sebesar 148,69 Mpa dari kelompok variasi elektroda E6013 dan mengalami kenaikan sebesar 10,41 Mpa dari kelompok variasi elektroda E7018. Nilai untuk tegangan luluh sebesar 308,53 Mpa, mengalami kenaikan sebesar 24,20 Mpa dari kelompok variasi elektroda E6013 dan mengalami kenaikan sebesar 9,31 Mpa dari kelompok variasi elektroda E7018. Nilai untuk regangan sebesar 35,6 \%, mengalami kenaikan sebesar 30,8 \% dari kelompok variasi elektroda E6013 dan mengalami kenaikan sebesar $15 \%$ dari kelompok variasi elektroda E7018.

3. Nilai rata-rata kekerasan untuk spesimen raw materials mempunyai nilai yang paling rendah jika dibandingkan dengan kelompok lainnya yang terletak pada logam induk yaitu sebesar $141,6 \mathrm{~kg} / \mathrm{mm}^{2}$.

4. Nilai rata-rata kekerasan untuk spesimen variasi elektroda E7018 mempunyai nilai kekerasan yang paling tinggi jika dibandingkan dengan kelompok lainnya yang terletak pada bagian logam las yaitu sebesar $189,6 \mathrm{~kg} / \mathrm{mm}^{2}$.

\section{UCAPAN TERIMAKASIH}

Penulis pada kesempatan ini mengucapkan terimakasih kepada semua pi g membantu baik berupa materi maupuı pıкı an sehingga penelitian dan paper ini dapat terselesaikan. Yang kedua penulis mengucapkan terimakasih kepada LP3M Universitas Muhammadiyah Yogyakarta atas bantuan dana penelitian melalui program penelitian dosen muda tahun 2017. Yang ke tiga penulis mengapresiasi Jurusan D3 Teknik Mesin Program Vokasi UMY atas fasilitas yang dipergunakan dalam penelitian ini.

\section{DAFTAR PUSTAKA}

Prasetyo H., 2006, Kekuatan tarik dari sambungan las baja tahan karat AIS 304 dengan baja karbon rendah SS 400, Skripsi, Universitas Sebelas Maret Surakarta.

Santoso J., 2005, Pengaruh arus pengelasan terhadap kekuatan tarik dan ketangguhan las SMAW dengan elektroda E7018, Skripsi, Universitas Negri Semarang.

Santoso T., 2011, Pengaruh arus listrik terhadap kuat pengelasan terhadap kekuatan tarik dan struktur mikro las SMAW dengan elektroda E7016, Skripsi, Universitas Negri Malang.

Wiryosumarto, 2000, Teknologi pengelasan logam, Pradnya Paramita, Jakarta. 